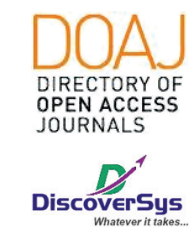

Published by DiscoverSys

\section{The endoscopy profile of patients with Gastrointestinal Bleeding (GIB) at Klungkung Regional General Hospital, Bali, Indonesia during the 2014-2018 period}

\author{
I Gede Restu Mahendra Sugiarta, ${ }^{1 *}$ I Ketut Sumandi ${ }^{2,3}$
}

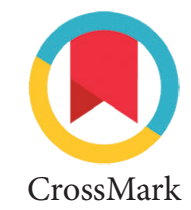

CrossMark

\begin{abstract}
Background: Gastrointestinal Bleeding (GIB) is an emergency case that often found in the condition. In Indonesia, the prevalence of GIB in the population is still unknown. Endoscopy is an examination procedure that used to see abnormalities in gastrointestinal mucosa or lumen of GIT, which is a relatively safe procedure to determine the causal of GIB. This study aims to evaluate the endoscopy profile of patients with GIB at Klungkung Regional General Hospital, Bali, Indonesia during the 2014-2018 period.

Methods: A descriptive cross-sectional study was conducted among the medical records of 410 patient's register who underwent endoscopy due to GIB during 2014-2018 period using total sampling technique at Klungkung Regional General Hospital, Bali, Indonesia. Variables assessed in this study included the sociodemographic of patients, type of endoscopy, and the outcome

of endoscopy procedure. Data were analyzed using SPSS version 21 for Windows.

Results: The highest proportion based on age were in the age of $51-60$ years-old (23.4\%) group. Males were predominant in this study (57.1\%) compared with females (42.9\%). Based on the type of endoscopy, Esophagogastroduodenoscopy (EGD) examination was predominant (80.7\%) compared with colonoscopy (19.3\%). Superficial Gastritis was the most common findings (41.5\%) from EGD, while colorectal tumours with suspected colorectal cancer and haemorrhoid (6.1\%) were predominant in colonoscopy evaluation.

Conclusion: The endoscopy profile found among patients with GIB at Klungkung Regional General Hospital, Bali, Indonesia was dominated by age 51-60 years-old group, males gender, EGD assessment, superficial Gastritis in EGD, and colorectal tumour in colonoscopy evaluation.
\end{abstract}

${ }^{1}$ General Practitioner, Faculty of Medicine, Universitas Udayana, Bali, Indonesia

${ }^{2}$ Department of Internal Medicine, Klungkung Regional General Hospital, Bali, Indonesia

${ }^{3}$ Endoscopy Unit, Klungkung Regional General Hospital, Bali, Indonesia

*Correspondence to:

I Gede Restu Mahendra Sugiarta;

General Practitioner, Faculty of

Medicine, Universitas Udayana, Bali, Indonesia;

dr.restumahendra@gmail.com

Received: 2019-07-11

Accepted: 2020-03-24

Published: 2020-04-01

Keywords: Profile, Proportion, GIB, Endoscopy, Klungkung, Hospital.

Cite This Article: Sugiarta, I.G.R.M., Sumandi, I.K. 2020. The endoscopy profile of patients with Gastrointestinal Bleeding (GIB) at Klungkung Regional General Hospital, Bali, Indonesia during the 2014-2018 period. Intisari Sains Medis 11(1): 306-309. D0I: 10.15562/ism.v11i1.565

\section{INTRODUCTION}

Gastrointestinal bleeding (GIB) is a part of disorder which bleeding occurred by several symptoms, such as fresh or black-red blood vomiting (hematemesis), blackish stool (melena), and fresh red stool (hematochezia). ${ }^{1}$ GIB divided by 2 parts, upper gastrointestinal bleeding (UGIB) and lower gastrointestinal bleeding (LGIB). There are separated by ligamentum treitz, the barrier between the upper gastrointestinal tract (UGT) and the lower gastrointestinal tract (LGT). ${ }^{2}$

GIB is an emergency case that often found in medical condition. According to British Society of Gastroenterology, the most common cause of UGIB is peptic ulcer with $26 \%$ cases. ${ }^{3}$ While according to literature review of Bai $\mathrm{Y}$ et al., the most common cause of LGIB in China includes colorectal cancer, colitis, anorectal disease, and inflammatory bowel disease (IBD). ${ }^{4}$

The prevalence of GIB in Indonesian's population is still unknown. Based on a preliminary survey at the Klungkung Regional General Hospital in 2019, the number of GIB cases obtained from
2014 to 2018 that examined with endoscopy was 410 cases.

Endoscopy is an examination's procedure that used to view the abnormal finding in gastrointestinal mucosa or lumen GIT, which is a relatively safe procedure to determine causal of GIB. Endoscopic examination of UGT is called Esophagogastroduodenoscopy (EGD) that includes the oesophagus, gaster until duodenum. ${ }^{5}$ While the endoscopic examination of LGT is called colonoscopy that provides for rectum, sigmoid colon, descending colon, transverse colon, ascending colon, cecum, and ileum. ${ }^{6}$

All results that obtained from endoscopic examination were variated by region. Based on Agustian's study, the description of EGD abnormalities in patients with dyspepsia that found at Cipto Mangunkusumo Hospital was gastritis with $41.2 \%$ cases. ${ }^{7}$ While from Azmi's study, the description of EGD abnormalities in patients with GIB that found at M. Djamil Central General Hospital, Padang, was peptic ulcer with $27.8 \%$ cases. ${ }^{8}$ However, the 
previous study conducted by Lubis $M$ found that the description of colonoscopy in patients with LGIB that found at Adam Malik Hospital, Medan, was Haemorrhoid with $44.7 \%$ cases. ${ }^{9}$

The exact cause of GIB in patients at Klungkung Regional General Hospital is unknown. With endoscopy, common causes of GIB can be found in patients at Klungkung Regional General Hospital. This study aims to evaluate the endoscopy profile of patients with GIB at Klungkung Regional General Hospital, Bali, Indonesia, during the 2014-2018 period.

\section{METHODS}

This research is a descriptive study using a cross sectional design that purpose to determine the profile of endoscopy patients with GIB based on patient's sociodemography (age and gender), type of endoscopy that used (EGD or Coloscopy), and results of endoscopy that found in Klungkung Regional General Hospital from 2014 until 2018 period.

This research was carried out in Endoscopy Unit, Klungkung Regional General Hospital, with consideration of available data from 2014 until 2018 regarding patients with GIB who underwent endoscopic examination. Data in this research is secondary data obtained from patient's register at Endoscopy Unit, Klungkung Regional General Hospital.

The population's target is all GIB patients that inward and outward in Klungkung Regional
General Hospital. While the population's affordable in this research are all patients with GIB who underwent endoscopy in Klungkung Regional General Hospital from 2014 until 2018. Samples in this study are all GIB patients who underwent endoscopy in Klungkung Regional General Hospital from 2014 until 2018. The number of samples in this study was 410 samples, using total sampling's method, obtained from results of a preliminary survey that conducted in the Endoscopic Unit, Klungkung Regional General Hospital, on 2019. Data that has been collected are analyzed using a computer with SPSS version 21 for Windows software.

\section{RESULTS}

From Table 1, the profile's proportion of endoscopy in patients with GIB at Klungkung Regional General Hospital from 2014 until 2018 is described in several categories. The proportion based on age is highest in the age 51-60 years-old group (23.4\%) and the lowest in the age $15-20$ years-old (1.0\%) (Table 1). Based on gender, males were predominant (57.1\%) compared with females (42.9\%). In addition, based on the type of endoscopy, EGD procedure was dominant with $80.7 \%$, while colonoscopy with $19.3 \%$ (Table 1 ). The results of endoscopy found in this study were varied, from EGD, the superficial gastritis was most frequent with $41.5 \%$, and the lowest diagnosis was Mallory-Weiss tear with $0.7 \%$ (Table 1). While from the colonoscopy, colorectal tumours were the most frequent with suspected colorectal cancer and haemorrhoid (6.1\%, respectively), and the lowest

Table 1 The profiles of endoscopy patients with GIB at Klungkung Regional General Hospital from 2014-2018 period

\begin{tabular}{lcc}
\hline Variables & Frequency $\mathbf{( N = 4 1 0 )}$ & Percentages $(\%)$ \\
\hline Age & & \\
$15-20$ years old & 4 & 1,0 \\
21 - 30 years old & 22 & 5,4 \\
$31-40$ years old & 51 & 12,4 \\
41 - 50 years old & 93 & 22,7 \\
51 - 60 years old & 96 & 23,4 \\
$61-70$ years old & 89 & 21,7 \\
$71-80$ years old & 47 & 11,5 \\
$81-90$ years old & 8 & 2 \\
Gender & & \\
Male & 234 & 57,1 \\
Female & 176 & 42,9 \\
Type of Endoscopy & & 80,7 \\
EGD & 331 & 19,3 \\
Colonoscopy & 79 & \\
\hline
\end{tabular}


Table 1 Continue

\begin{tabular}{lcc}
\hline Variables & Frequency $\mathbf{( N = 4 1 0 )}$ & Percentages (\%) \\
\hline Outcome of Endoscopy & & \\
EGD & 170 & 41,5 \\
Superficial Gastritis & 58 & 14,1 \\
Erosive Gastritis & 26 & 6,3 \\
Peptic Ulcer & 9 & 2,2 \\
Duodenal Ulcer & 14 & 3,4 \\
Gastric Tumor susp. Cancer & 14 & 3,4 \\
GERD & 27 & 6,6 \\
Gastritis with Worm Infection & 9 & 2,2 \\
Esophageal Varices & 4 & 1,0 \\
Portal Hypertensive Gastropathy & 3 & 0,7 \\
Mallory-Weiss Tear & & 6,1 \\
Colonoscopy & 25 & 2,0 \\
Colorectal Tumor susp. Cancer & 8 & 3,9 \\
Colitis & 16 & 6,1 \\
Proctitis & 25 & 0,5 \\
Hemorrhoids & 2 & \\
Normal Results of Endoscopy & & \\
\hline
\end{tabular}

diagnosis based on colonoscopy was colitis with $2.0 \%$. There is also typical endoscopy result with $0.5 \%$ among the cases (Table 1 ).

\section{DISCUSSION}

The profile's proportion in Klungkung Regional General Hospital based on age is highest at the age of 51 to 60 years at $23.4 \%$. This is consistent with the study by Azmi et al., which stated that the proportion of endoscopic profiles in M. Djamil Central Hospital, Padang, was highest at the age of 51 to 60 years with $29.0 \% .^{8}$

Age is one of the risk factors for GIB. GIB can occur both in young and old. However, older adults are the most frequent group cases of GIB. In Upper Gastrointestinal Bleeding (UGIB), it caused by several factors (reduced mucosal protective mechanisms, altered gastric microbiota, $H$. pylori infection, and increased NSAIDs or aspirin use). ${ }^{10,11}$ While in Lower Gastrointestinal Bleeding (LGIB), it caused by several factors (an ageing process that effect to gastrointestinal motility and mucosal or lumen thinning, inflammatory process due to infection or autoimmune in LGT, and presence of tumours due to genetic mutations). ${ }^{10}$

The profile's proportion in Klungkung Regional General Hospital based on gender is higher in males with $57.1 \%$, while females with $42.9 \%$. This is consistent with the study by Azmi at al., in 2016 which stated that the proportion of endoscopic profiles in M. Djamil Central Hospital, Padang, based on gender was higher in male with $64.8 \%$, while females with $35.2 \%{ }^{8}$ However, it hasn't been able to determine the definite cause of male that suffering GIB more often than female.

The proportion of Endoscopy profiles in Klungkung Regional General Hospital based on the type of Endoscopy is higher in EGD with $80.7 \%$, while colonoscopy with $19.3 \%$. This is in accordance with the study of Kaminang which stated that the proportion of endoscopic profiles in Prof. Dr R. D. Kandou Central Hospital, Manado, based on the type of Endoscopy was higher in EGD with $80 \%$. In comparison, colonoscopy with $20 \% .{ }^{12}$ UGIB is the most common case GIB that compared to LGIB because patients with LGIB are rarely going to the hospital so that the case of LGIB that found were underreported. ${ }^{13}$ Thus, the use of EGD is more often at all hospitals, especially in Klungkung Regional General Hospital, compared to colonoscopy in the case of GIB.

The profile's proportion of Endoscopy in Klungkung Regional General Hospital based on results of Endoscopy is highest in superficial gastritis with $41.5 \%$ from EGD examination. In comparison, colonoscopy analysis is more elevated in colorectal tumours with suspected colorectal cancer and haemorrhoid with $6.1 \%$. A previous study by Azmi et al., also found that the proportion of endoscopic profiles in M. Djamil Central Hospital, Padang, based on results of Endoscopy is highest in multi 
lesions of $38.3 \%$ from EGD examination. ${ }^{8}$ However, the previous results are not consistent with the study by Anand et al., in 2014 which found that the proportion of endoscopic profiles in North India Hospital based on results of Endoscopy is highest in Portal Hypertension Gastropathy (PHG) with $56.14 \%$ from EGD examination. ${ }^{14}$ But, the results were consistent with the study by Lubis et al., in 2012 where the proportion of endoscopic profiles in Adam Malik Hospital, Medan, based on results of Endoscopy is highest in haemorrhoid with $44.1 \%$ from colonoscopy examination. ${ }^{9}$ The Endoscopy's result that recorded in Endoscopy Unit, Klungkung General Hospital, depending on the interpretation of internal medicine specialist who was on duty at endoscopy unit, based on the Endoscopy's finding. Any findings that obtained from Endoscopy (EGD or colonoscopy) have a different characteristic of lesions. Based on EGD, superficial gastritis is most common recorded because the lesion that found are hyperemic without erosion or gastric ulcers. While based on colonoscopy, colorectal tumour and haemorrhoid are more common because of the mass that found in the colon or the rectum or anus.

\section{CONCLUSION}

Endoscopy is an examination procedure to determine abnormalities in gastrointestinal mucosa or lumen GIT. Endoscopy that performed in Klungkung Regional General Hospital is divided into two types, EGD and Colonoscopy. EGD was more often used for patients with GIB than Colonoscopy. Based on EGD, superficial gastritis was most common recorded in the Endoscopy Unit, Klungkung Regional General Hospital. By knowing the profile of Endoscopy in patients with GIB at Klungkung Regional General Hospital, hoped that it could provide definitive and adequate treatment for patients with GIB.

\section{CONFLICT OF INTEREST}

None.

\section{ETHICS CONSIDERATION}

Ethics approval has been obtained prior to the study being conducted from Ethics Committee, Faculty of Medicine, Universitas Udayana and Klungkung Regional General Hospital, Bali, Indonesia.

\section{FUNDING}

The authors are responsible for the funding of study without involvement of grant, scholarship, sponsorship, or any other resources of funding.

\section{AUTHOR CONTRIBUTION}

All of authors are equally contributed to the study from the conceptual framework, data gathering, data analysis, until interpreting the results of study through publication.

\section{REFERENCES}

1. Nable JV, Graham AC. Gastrointestinal Bleeding. Emerg Med Clin North Am. 2016;34(2):309-325.

2. Kim BS, Li BT, Engel A, Samra JS, Clarke S, Norton ID, et al. Diagnosis of gastrointestinal bleeding: A practical guide for clinicians. World J Gastrointest Pathophysiol. 2014;5(4):467-478.

3. Penny HA, Kurien M, Wong E, Ahmed R, Ejenavi E, Lau M, et al. Changing trends in the UK management of upper GI bleeding: is there evidence of reduced UK training experience?. Frontline Gastroenterol. 2016;7(1):67-72.

4. Bai Y, Peng J, Gao J, Zou DW, Li ZS. Epidemiology of lower gastrointestinal bleeding in China: single-center series and systematic analysis of Chinese literature with 53,951 patients. J Gastroenterol Hepatol. 2011;26(4):678-682.

5. Kim KO. Normal Upper GI Findings and Normal Variants. In: Chun H, Yang SK, Choi MG. (eds) Clinical Gastrointestinal Endoscopy. Springer, Singapore. 2018, p.1-11.

6. Lombard MG, Morris AI, Morris AJ, Rosch T. Lower Gastrointestinal Tract. In: Atlas of Gastrointestinal Endoscopy and Related Pathologi (2nd ed). UK: Blackewell Science. 2004; p.227-8.

7. Agustian H, Makmun D, Soejono CH. Gambaran Endoskopi Saluran Cerna Bagian Atas pada Pasien Dispepsia Usia Lanjut di Rumah Sakit Umum Cipto Mangunkusumo. Jurnal Penyakit Dalam Indonesia. 2015;2(2):87-89.

8. Azmi FA, Miro S, Iryani D. Gambaran EGD Pasien Hematemesis dan atau Melena di RSUP M. Djamil Padang Periode Januari 2010 - Desember 2013. Jurnal Kesehatan Andalas. 2016;5(1):10-15.

9. Lubis M, Zain LH. Etiology Profile of Lower Gastrointestinal Bleeding. The Indonesian Journal of Gastroenterology Hepatology and Digestive Endoscopy. 2012;13(2):94-96.

10. Dumic I, Nordin T, Jecmenica M, Stojkovic Lalosevic M, Milosavljevic T, Milovanovic T. Gastrointestinal Tract Disorders in Older Age. Can J Gastroenterol Hepatol. 2019;2019:6757524.

11. Lanas A, Chan FKL. Peptic ulcer disease. Lancet. 2017; 390(10094):613-624.

12. Kaminang GA, Waleleng BJ, Polii EB. Profil Endoskopi Gastrointestinal di RSUP Prof. Dr. R. D. Kandou Manado periode Januari 2016 - Agustus 2016. Jurnal E-Clinic (ECl). 2016;4(2):1-7.

13. Ghassemi KA, Jensen DM. Lower GI bleeding: epidemiology and management. Curr Gastroenterol Rep. 2013;15(7):333. doi:10.1007/s11894-013-0333-5.

14. Anand D, Gupta R, Dhar M, Ahuja V. Clinical and Endoscopic Profile of Patients with Upper Gastrointestinal Bleeding at Tertiary Care Center of North India. Journal of Digestive Endoscopy. 2014;5(4):139-143.

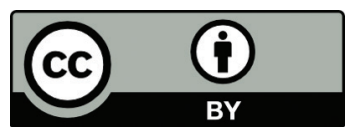

This work is licensed under a Creative Commons Attribution 